\title{
Rancang Bangun Alat Musik Berbasis Perubahan Arus Perpindahan
}

\author{
Muhammad Dwi Rifqi, Gamantyo Hendrantoro, dan Wirawan \\ Departemen Teknik Elektro, Fakultas Teknologi Elektro, Institut Teknologi Sepuluh Nopember (ITS) \\ E-mail: gamantyo@yahoo.com
}

\begin{abstract}
Abstrak-Studi ini dilakukan untuk mengetahui perubahan frekuensi pada alat musik Theremin pada saat dimainkan dengan menyesuaikan jarak tangan pemain dengan antena. Konsep dari Theremin ini adalah sebuah alat musik, dimana cara memainkan alat musik tersebut tidak menggunakan kontak fisik langsung terhadap alat tersebut, dimana menggunakan teori arus perpindahan yaitu suatu medan listrik yang berubah terhadap waktu yang dimana arus perpindahan itu akan terjadi ketika terdapat dua lempeng penghantar atau kapasitor pada suatu dielektrik yang diberikan tegangan dan akan menghasilkan medan listrik. Pada alat ini juga terdapat prinsip heterodinamis dimana terdapat dua frekuensi antena yang bercampur yang saling mengurangi sehingga menghasilkan frekuensi yang dapat didengar oleh telinga manusia. Pada eksperimen dapat dilihat hasilnya bahwa pada saat tangan pemain mendekati antena, frekuensi yang akan dihasilkan akan semakin besar sehingga menghasilkan nada yang lebih tinggi, begitu juga sebaliknya.
\end{abstract}

Kata Kunci-Hukum Maxwell, Karakteristik Pitch Controll, Perubahan Frekuensi, Theremin.

\section{PENDAHULUAN}

$I^{\mathrm{N}}$ NDUSTRI kreatif musik dengan mencipatakan alat musik elektronik di Indonesia dibutuhkan kreativitas dan perkembangan dalam dunia musik elektronik. Seperti yang kita tahu bahwa alat musk elektronik ini memiliki ragam musik elektronik yang perkembanganya belum signifikan. Perkembangan musik Theremin di Indonesia masih terbilang jarang bahkan banyak masyarakat Indonesia yang belum mengetahui alat tersebut. Theremin adalah alat musik yang dimana cara memainkan alat musik tersebut yaitu menggunakan tangan pemain tanpa menyentuh alat tersebut, perubahan nada tersebut akan diatur melalui jarak pemain dengan antena dari Theremin tersebut.

Pada Medan Elektromagnetik terdapat konsep Arus Perpindahan yang merupakan cara kerja dari alat Theremin ini, dimana menjelaskan bagaimana suatu medan listrik yang berubah terhadap waktu akan menghasilkan suatu medan magnet karena adanya arus perpindahan tersebut. Arus perpindahan ini akan terjadi ketika terdapat dua lempeng kapasitor yang diberikan tegangan yang berubah terhadap waktu yang disusun secara paralel sehingga kedua lempeng tersebut akan menghasilkan medan listrik. Pada teori arus perpindahan ini juga akan menjelaskan keterkaitan dengan persamaan Maxwell bahwa medan listrik dan arus perpindahan ini dapat menimbulkan suatu medan magnet.

Pada alat Theremin ini juga terdapat prinsip heterodinamis, dimana prinsip tersebut menjelaskan pencampuran antara dua frekuensi yang akan menghasilkan frekuensi resonansi baru, dengan menggunakan rumus heterodinamis, dua frekuensi yang berada pada Theremin ini dihasilkan pada rangkaian yang digunakan yaitu rangkaian refrensi dan rangkaian penyetara dengan nilai yang ditentukan oleh nilai dari masing-masing induktor dan kapasitor. Pada prinsip heterodinamis ini dihapharapkan frekuensi resonansi yang dihasilkan dari pencampuran dua frekuensi tersebut menghasilkan frekuensi yang sama yaitu pada saat posisi alat bernilai zero dimana Theremin dalam posisi diam atau tidak mengeluarkan suara, yang nantinya cara merubah penggunaan frekuensi sehingga menghasilkan suara tersebut akan digunakan device antena yang berfungsi sebagai pengubah kapasitansi yang akan diganggu medan dielektriknya menggunakan tangan pemain sehingga terjadi perubahan frekuensi output yang dihasilkan. Pada rangkaian yang digunakan pada Theremin ini juga akan dilakukan analisa terkait jenis osilator yang digunakan, yaitu osilator Hartley dimana osilasi ini bekerja pada saat terdapat sambungan dari pusat induktor yang diserikan atau menarik tapped coil induktor dari pusat yang dihubungkan ke komponen transistor pada bagian emitter, osilator ini juga memiliki pengaturan pada induktor dan kapasitor untuk mendapatkan hasil berupa frekuensi resonansi.

Berdasarkan uraian diatas permasalahan studi yang akan dibahas dalam studi ini yaitu menganalisa frekuensi yang dihasilkan dari alat Theremin dengan dua metode, yaitu analisa pengukuran Theremin pada saat tidak tidak dimainkan yang artinya Theremin tidak menggunakan device antena dan kontrol suara yang dihasilkan dari Theremin ini akan dikendalikan dengan pengubahan nilai variabel kapasitor, yang dilanjutkan dengan analisa pengukuran Theremin pada saat alat tersebut dimainkan. Setelah dilakukan pengukuran kedua metode tersebut akan dilihat hasil dari jarak nada yang dihasilkan. Dan juga permasalah lain yang akan dibahas adalah terkait Kalibrasi nada dasar dari Theremin. Tujuan dari penelitian studi terkait perancangan Theremin ini adalah dapat membuat suatu inovasi baru dalam perkembangan dunia musik elektrik, dapat menginspirasi para musisi untuk membuat atau memainkan Theremin dan juga dapat mengetahui faktor-faktor apa saja yang dapat mempengaruhi terkait frekuensi yang dihasilkan Theremin.

\section{STUDI LITERATURE}

\section{A. Arus Perpindahan}

Teori Arus Perpindahan ini menjelaskan bagaimana sebuah medan listrik yang akan berubah terhadap waktu yang akan menghasilkan medan magnet karena adanya arus perpindahan. Dan juga menjelaskan bahwa arus perpindahan ini akan bekerja pada saat arus listrik pada medan tersebut bernilai nol. Dan juga penyempurnaan teori terhadap arus perpindahan yaitu koreksi Maxwell terhadap Hukum Ampere yang menyatakan bahwa perubahan medan listrik dan arus perpindahan dapat menimbulkan suatu medan magnet [1]. 


\section{B. Heterodinamis}

Metode Heterodinamis adalah suatu metode pengukuran frekuensi dengan nilai frekuensi yang tinggi. Pada theremin ini prinsip heterodinamis digunakan untuk menghasilkan suatu sinyal audio.

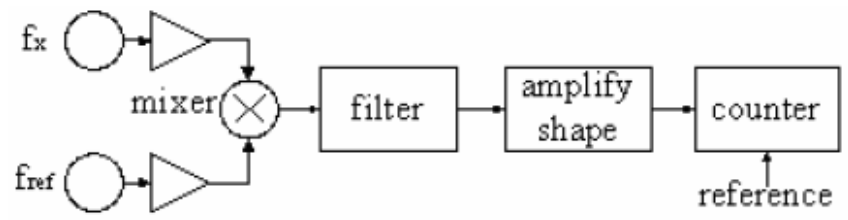

Gambar 1. Prinsip kerja heterodinamis

Frekuensi yang pertama dihasilkan dari rangkaian refrensi atau frekuensi refrensi (fref) dan yang kedua adalah frekuensi yang dihasilkan dari rangkaian penyetara (fx). Kedua frekuensi tersebut akan selanjutnya akan digabungkan pada mixer dan akan menghasilkan frekuensi resonansi. Frekuensi resonansi ini dapat dihitung dengan menggunakan rumus [2].

$$
f r=f r e f-f x
$$

Dimana, fr $=$ frekuensi resonansi

Fref $=$ frekuensi refrensi

$\mathrm{Fx}=$ frekuensi penyetara

\section{Hartley Oscillator}

Hartley Oscillator adalah jenis osilator yang bekerja pada saat terdapat rangkaian yang dilakukan pengaturan pada induktor dan kapasitor dengan susunan paralel. Hartley oscilator ini memiliki fungsi untuk mencari frekuensi resonansi pada suatu rangkaian yang ditentukan dari nilai kapasitor dan induktor yang sesuai dengan osilasi tersebut. Untuk melihat hasil osilasi diperlukan koneksi dari pusat induktor yang diseri atau menarik tapped coil induktor dari pusat yang terhubung dengan suatu komponen yaitu transistor pada bagian emitter [3].

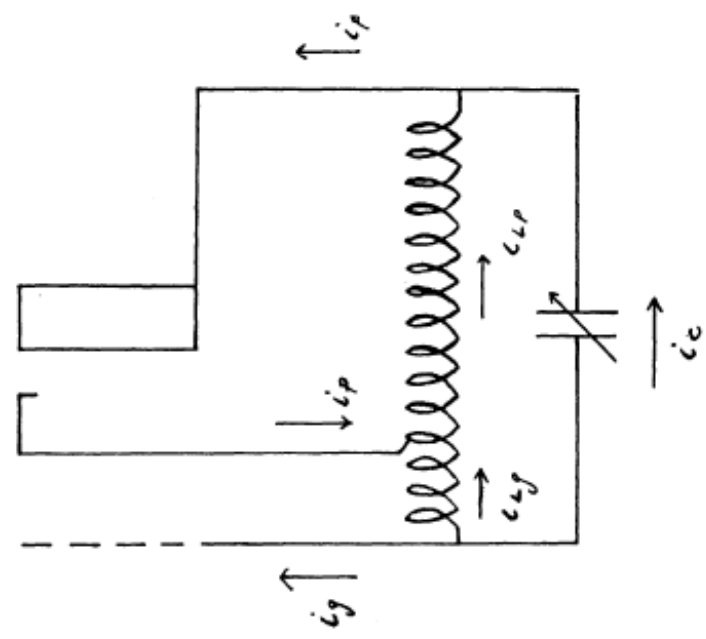

Gambar 2. Diagram Schematic Hartley Osilator

Pada Harley Oscillator ini dapat ditentukana frekuensi resonansi dari Theremin dengan melihat komponen dari induktor dan kapasitor tersebut dengan menggunakan rumus

$$
f r=\frac{1}{2 \pi \sqrt{L C}}
$$

Dimana, $\mathrm{fr}=$ frekuensi resonansi

$$
\begin{aligned}
& \mathrm{L}=\text { nilai induktor } \\
& \mathrm{C}=\text { nilai kapasitor }
\end{aligned}
$$

\section{Theremin}

Cara kerja Theremin ini adalah dengan menggerakan tangan pemain mendekat dan menjauhi antena pada pitch control maupun volume control. Tangan pemain tersebut akan mengubah kapasitansi yang berada pada sirkuit tersebut yang akan merubahnya menjadi frekuensi osilasi. Penggunaan antena tidak dengan spesifikasi yang jelas tidak terlalu dibtuhkan dalam Theremin ini karena antena disini berfungsi untuk mengubah kapasitansi dari kapasitor yang terdapat pada rangkaian tersebut. Theremin ini juga memiliki 2 frekuensi yang akan saling mengurangi sehingga menghasilkan suatu suara, yang diharapkan sebelum memainkan Theremin tersebut adalah Theremin berada pada posisi diam yang artinya kedua frekuensi yang dihasilkan sebelum dimulai permainan memilki nilai yang sama sehingga frekuensi bernilai zero atau nol. Cara kerja Theremin ini juga diadopsi dari teori arus perpindahan medan elektromagnetik dimana terdapat dua kapasitor yaitu antena dan tangan pemain. Tangan pemain ini akan mengganggu dielektrik udara mendekat dan menjauhi antena yang akan mengubah nilai kapasitansi dari kapasitor pada rangkaian Theremin tersebut [4]

Teknik permainan dari Theremin bisa dikatakan sangat sulit karena pemain harus mengsinkronasikan kedua tangan dengan kedua antena tersebut, dimana diharapkan pemain dapat mengendalikan pengaturan nada dan volume secara bersamaan. Biasanya pemain theremin ini menggunakan tangan kananya untuk mengatur tinggi rendahnya nada, sedangkan tangan kirinya untuk mengatur besar kecilnya suara yang dihasilkan [5].

\section{METODE PERANCANGAN DAN PENGUKURAN THEREMIN}

Pada perancangan dan pengukuran Theremin akan digunakan rangkaian Theremin

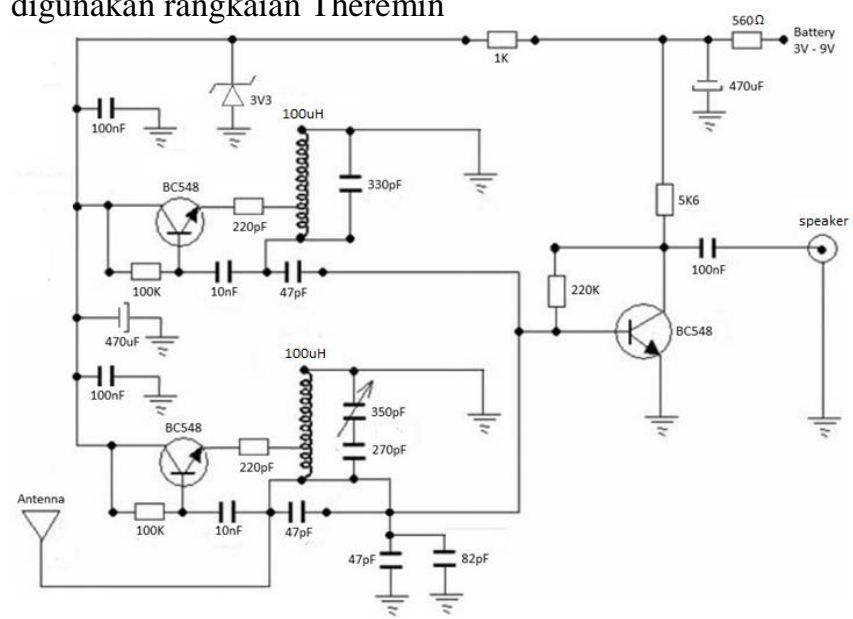

Gambar 3. Rangkaian Theremin

\section{A. Pengukuran Theremin Sebelum Dimainkan}

Pada pengukuran Theremin sebelum dimainkan ini dilakukan hanya untuk melihat jarak nada yang dihasilkan dari Theremin tanpa menggunakan device antena dan tangan pemain yang artinya suara yang dihasilkan dari Theremin berasal dari pengaturan variabel kapasitor. Hasil dari 
Theremin sebelum dimainkan ini didapatkan dari prinsip heterodinamis dimana frekuensi refrensi dikurangi atau ditambahkan frekuensi penyetar, yang dimana pendengaran manusia dapat mendengar yaitu sampai $20 \mathrm{KHz}$.

\section{B. Pengukuran Theremin Setelah Dimainkan}

Pada pengukuran Theremin setelah dimainkan ini yaitu penggunaan device antena sudah dipasangkan pada Theremin dan juga dirubah menggunakan tangan pemain. Dalam proses pengukuran ini hal pertama yang dilakukan adalah mencari posisi zero pada Theremin yang artinya frekuensi refrensi dan frekuensi penyetara memiliki nilai yang sama sehingga Theremin berada pada posisi diam atau tidak mengeluarkan suara. Setelah didapatkan posisi zero selanjutnya adalah proses memainkan Theremin tersebut dengan menggunakan tangan pemain mendekati dan menjauhi antena. Setelah dilakukan permainan Theremin selanjutnya adalah proses pengukuran dengan menggunakan aplikasi spectrum analyzer seperti equalizer, dan hasil dari suara yang dihasilkan Theremin akan terdeteksi oleh aplikasi tersebut.

\section{Kalibrasi Theremin}

Pada proses kalibrasi Theremin ini bertujuan untuk memadukan suara yang dihasilkan Theremin dengan alat musik lain. Dalam proses kalibrasi Theremin digunakan beberapa perangkat tambahan seperti pitch pipe dimana fungsi pitch pipe tersebut adalah menyelaraskan suara yang dihasilkan dari Theremin dengan suara dari pitch pipe tersebut sesuai dengan kunci yang tertera pada pitch pipe dan chromatic tuner dimana fungsi dari chromatic tuner ini akan mengeluarkan note nada yang dihasilkan dari Theremin.

\section{HASIL DAN ANALISIS DATA}

\section{A. Analisa Rangkaian Theremin}

Analisa yang dilakukan adalah terkait jenis osilator. Jenis osilator disini menggunakan jenis Hartley Osilator dimana terdapat komponen yang dihubungkan dengan pusat dari tapped induktor. Fungsi dari osilator Hartley ini yaitu untuk menghitung frekuensi resonansi dari osilasi tersebut yang dihasilkan dari nilai induktor dan kapasitor. Rangkaian refrensi dan rangkaian penyetara memiliki jenis osilasi yang sama hanya terdapat perbedaan pada nilai dari komponen yang digunakan. Selanjutnya analisa terhadap masing-masing rangkaian yaitu rangkaian refrensi dan rangkaian penyetara, analisa terhadap hasil frekuensi rangkaian tersebut menggunakan osiloskop dan juga perhitungan langsung dengan menggunakan perhitungan frekuensi resonansi. Dengan mengambil satu contoh yaitu pada rangkaian refrensi jika dilakukan dengan menggunakan perhitungan,

$$
\begin{aligned}
& f r=\frac{1}{2 \pi \sqrt{L C}} \\
& f r=\frac{1}{2 \pi \sqrt{100 \times 10^{-6} \times 330 \times 10^{-12}}} \\
& f r=876,119 \mathrm{KHz}
\end{aligned}
$$

Sedangkan hasil dengan menggunakan osiloskop.

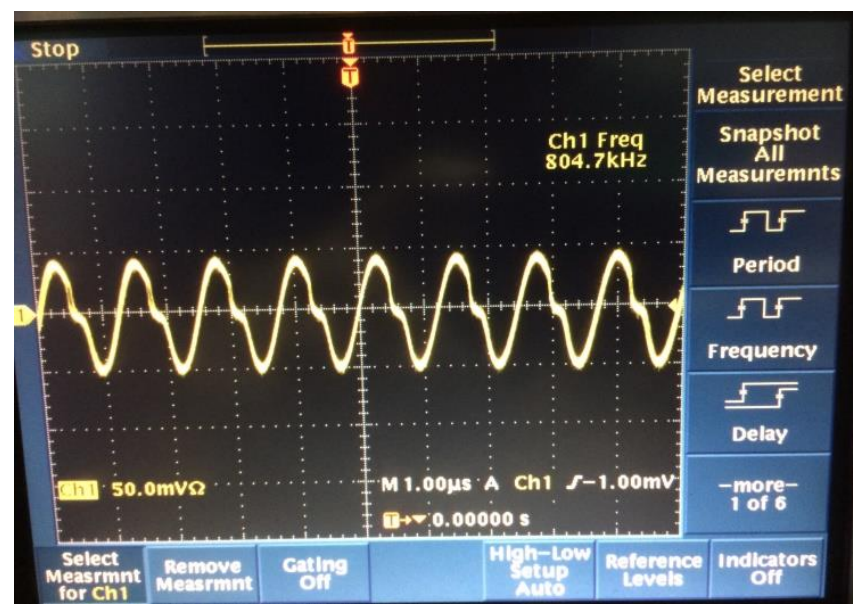

Gambar 4. Frekuensi refrensi

Dari kedua hasil tersebut terdapat perbedaan perhitungan yang disebabkan komponen yang digunakan tidak bernilai setara seperti penggunaan induktor, karena induktor menggunakan jenis lilitan, nilai dari induktor tersebut tidak bernilai pas. Begitu juga dengan rangaian penyetara dilakukan dengan 2 pengukurang tersebut dan mendapatkan hasil yang berbeda juga, yang dikarenakan karena komponen kapasitor yang berbeda-beda. Hasil yang dimasukkan dalam pengukuran selanjutnya adalah hasil dari pengukuran menggunakan osiloskop.

\section{B. Analisis Theremin Sebelum Dimainkan}

Analisa terhadap Theremin sebelum dimainkan ini yang pertama kali dilakukan adalah hasil frekuensi yang ditunjukkan frekuensi refrensi sebesar $804,7 \mathrm{KHz}$ tersebut dikurangi dan ditambahkan dengan frekuensi yang bisa terdengan oleh manusia yaitu $20 \mathrm{KHz}$. Pada pengukuran ini dilakukan pengurangan pada perhitunagan dengan memutar komponen variabel kapasitor untuk mendapatkan frekuensi tersebut dengan tujuan frekuensi manakah yang akan bekerja, jika frekuensi refrensi lebih kecil dari frekuensi penyetara atau bernilai lebih dari $804,7 \mathrm{KHz}$ dengan hasil perhitungan dengan menggunakan rumus heterodinamis bernilai mines maka frekuensi yang bekerja adalah frekuensi penyetara begitu juga sebaliknya jika frekuensi refrensi lebih besar atau kurang dari 804,7 KHz dengan hasil perhitungan positif, maka frekuensi yang bekerja adalah frekuensi refrensi. Dengan mangambil satu sample hasil dari perhitungan dan osiloskop,

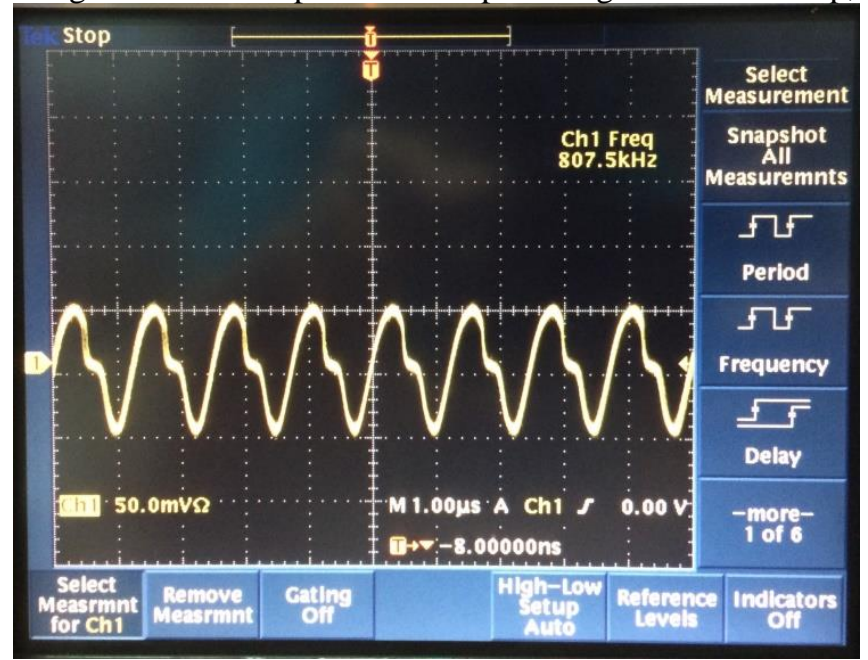

Gambar 5. Frekuensi pada saat pemutaran variabel kapasitor

Dengan melakukan perhitungan terhadap hasil tersebut akan terlihat frekuensi manakah yang akan bekerja. 
$f r=804,7 \mathrm{KHz}-807,5 \mathrm{KHz}$

$f r=-2,8 \mathrm{KHz}$

Dapat dilihat hasil frekuensi tersebut bernilai mines yang artinya frekuensi yang bekerja adalah frekuensi penyetara, pengukuran dilanjutkan pada saat Theremin mengeluarkan dengan nada yang berbeda. Dapat disimpulkan dari pengukuran Theremin sebelum dimainkan yang dapat didengar oleh pendengaran manusia mencapai 5 sampai 6 tangga nada.

\section{Anlisa Theremin Setelah Dimainkan Dan Kalibrasi Theremin}

Analisa yang dilakukan pada Theremin dimainkan pertama kali adalah mencari nilai zero yaitu posisi Theremin tidak mengeluarkan suara dengan mengatur variabel kapasitor dengan menggunakan osiloskop.

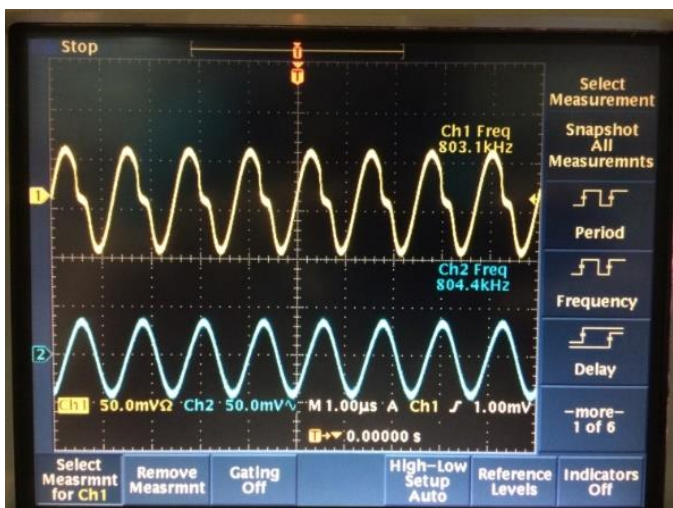

Gambar 6. Frekuensi zero

Dalam mencari posisi zero ini masih terbilang sulit dikarenakan pada saat proses pemutaran variabel kapasitor, ketika diputar sedikit saja bisa merubah frekuensi mencapai $3 \mathrm{KHz}$ samapai $4 \mathrm{KHz}$. Setelah mendapatkan posisi zero selanjutnya adalah proses pengukuran Theremin saat dimainkan dengan melakukan 4 pengukuran waktu yang berbeda-beda dan hasil yang diambil adalah hasil dengan oktaf tertinggi.

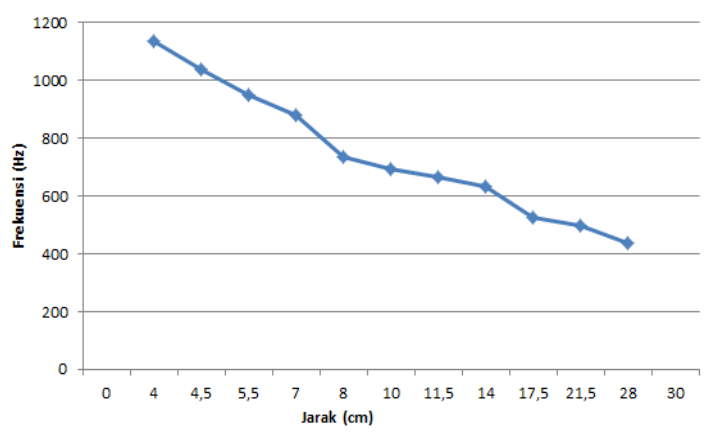

Gambar 7. Frekuensi refrensi

Setelah mendapatkan hasil frekuensi yang dihasilkan dari Theremin, dari data tersebut akan dilakukan dengan proses kalibrasi Theremin yaitu penentuan nada dasar yang dihasilkan dari Theremin.
Tabel 1.

Hasil frekuensi dan kalibrasi Theremi

\begin{tabular}{cccccc}
\hline \hline No & Nada & $\begin{array}{c}\text { Jarak } \\
(\mathrm{cm})\end{array}$ & $\begin{array}{c}\text { Frekuensi } \\
(\mathrm{Hz})\end{array}$ & Note & Oktaf \\
\hline 1 & $\mathrm{Do}$ & 28 & 438 & $\mathrm{~A}$ & 4 \\
2 & $\mathrm{Re}$ & 21,5 & 496 & $\mathrm{~B}$ & 4 \\
3 & $\mathrm{Mi}$ & 17,5 & 526 & $\mathrm{C}$ & 5 \\
4 & $\mathrm{Fa}$ & 14 & 634 & $\mathrm{D \#}$ & 5 \\
5 & $\mathrm{Sol}$ & 11,5 & 666 & $\mathrm{E}$ & 5 \\
6 & $\mathrm{La}$ & 10 & 693 & $\mathrm{~F}$ & 5 \\
7 & $\mathrm{Si}$ & 8 & 737 & $\mathrm{~F} \#$ & 5 \\
8 & $\mathrm{Do}$ & 7 & 881 & $\mathrm{~A}$ & 5 \\
9 & $\mathrm{Re}$ & 5,5 & 951 & $\mathrm{~A}^{\prime} \#$ & 5 \\
10 & $\mathrm{Mi}$, & 4,5 & 1039 & $\mathrm{C}$ & 6 \\
11 & $\mathrm{Fa}$ & 4 & 1137 & $\mathrm{C}^{\prime} \# / \mathrm{D}$ & 6 \\
\hline \hline
\end{tabular}

Tujuan dari pengukuran terhadap 4 waktu yang berbeda yaitu untuk melihat apakah terdapat perbedaan dari Theremin tersebut dan juga kalibrasi tersebut untuk menyelaraskan Theremin dengan alat musik lain.

\section{KESIMPULAN}

Kesimpulan yang dapat diambil perancangan Theremin ini adalah dengan menggunakan rangkaian tersebut didapatkan hasil kalibrasi Theremin berada pada note A dan Theremin dapat mencapai tangga nada setinggi 1,5 oktaf. Dengan merubah beberapa komponen kapasitor dan induktor pada rangkaian Theremin dapat mempengaruhi frekuensi resonansi dari Theremin sehingga jarak tangan pemain dengan antena juga dapat berubah.

Antena yang digunakan pada Theremin tidak menggunakan antena dengan spesifikasi yang spesifik, antena yang digunakan berupa antena telescope. Fungsi dari antena ini untuk merubah kapasitansi dari kapasitor.

\section{DAFTAR PUSTAKA}

[1] A. J. Hayt, H. William and Buck, Engineering Electromagnetics, Seventh Edition. New York: McGraw-Hill College, 2004.

[2] Y. Li, Xiaouhi, Wang, Danni and Bian, "Heterodyne Frequency Measurement Method Based on Virtual Instrumen," Chinese Academy of Sciences, 2007.

[3] S. . Record, F.A and Stiles, "An Analytical Demonstration of Hartley Oscilator," 1943.

[4] N. P, "Leon Theremin (Lev Theremin)," Intermec Technol., 2012

[5] N. Derek, Lindberg, Nick, Ciocco and Greg, "Capacitive Pitch Controll Theremin," University of Colorado, 2019. 